\title{
Leadership Ethics of Social Market Economy A Model to Identify and Cultivate Capability Freedom
}

\author{
Elmar Nass \\ Wilhelm Loehe University of Applied Sciences \\ Professur Wirtschafts- und Sozialethik (Professorship for Economic and Social Ethics) \\ Merkurstr. 41, D-90763 Fuerth, Germany
}

Received: Sep. 10, 2018 Accepted: Oct. 2, 2018 Online published: Oct. 11, 2018

doi:10.5296/ijhrs.v8i4.13763ＵRL: https://doi.org/10.5296/ijhrs.v8i4.13763

\begin{abstract}
A compendium to identify leadership ethics of social market economy will be introduced as a model. Theoretical concepts have to answer the question how to deal with the dualism of responsibility concerning efficiency and human targets in the management culture. They can be identified in four steps by means of principles and perspectives as a strong or weak leadership ethic of social market economy. Consequently, there is a recommendation with regard to its use.
\end{abstract}

Keywords: leadership ethics, ordo-liberalism, capability approach, macro-micro-perspective, social market economy, classification tool

\section{In the Jungle of Leadership Ethics}

Social market economy has become an empty word. The liberals and the politically left claim it for themselves. Accordingly, the citation of it has forfeited the power of orientation. The following article wants to counteract this development from a business ethical point of view by newly activating capability freedom as a stimulating culture of social market economy on an entrepreneurial level. Not only the government but also business enterprises with their transactions and management culture shape the economy's institutional regulatory framework; which in turn influences the behaviour of companies. The level of order can help form responsibly with such a dynamic-reciprocal evolutionary process ensuing from companies. Social market economy as a cultural program of social peace according to Müller-Armacks particularly understands itself as a normative cultural idea.

The impetus selected here takes the meso level of ethical leadership culture as a starting point because it introduces the regulatory idea of a cultural programme of social solidarity as on the macro level. Leadership should not be understood as the task of the personnel management 
alone but in the broader sense as intended influencing of behaviour (von Oelsnitz, 2012, p. 8). It is in all divisions, departments and hierarchy levels the responsible impact of the employees' behaviour (Kuhn \& Weibler, 2012, p.15) as it is a subject of ethics. Leadership culture is "a composite of people's behaviour within the organization and in the underlying shared beliefs, meanings and values, the norms commonly applied and the practices carried out" (Melé \& Cantón, 2014, p. 45). It is involved contextually in the social culture and characterizes it normatively according to the style conception. Therefore criteria of leadership ethics should be determined; they correspond at the same time to the normative basic idea of social market economy. Concepts like this should be used in enterprises. So it gives companies an orientation in this jungle. With that one can succeed in theoretically re-sharping the profile of a culture of social market economy in Germany and revitalizing it practically by appropriately identified leadership ethics and culture on the meso-level. An identification and cultivation approach like this is not trivial at all. The normative fundamentals often take a back seat behind the vividly presented hand tools of effective management in the case of the ethical seeming concepts of leadership; consequently, also the term ethic has become an empty word. Therefore, the present deductive contribution wants to offer a manual as a model to distinguish between leadership ethics and theory of leadership from an ordoliberal point of view and to identify the compatibility of offered ethical attempts on the basis of relevant ethical perspectives with clear normative principles. With this approaches of leadership ethics can be classified as belonging to the relevant schools that appeal to social market economy, either correctly or unjustly. This includes no reconstruction or even a new draft of a theory of economic order as a reference. In fact, the relevant source of values for this field and the consequent principals could be applied identified for the leadership ethic of social market economy.

\section{A Guideline}

\subsection{Fundamental Questions of Value Basis}

The guideline developed in the following text is assistance to the orientation to identify leadership ethics that are compatible with the basic ideas of social market economy. It follows that collectivistic or free market-economy based ethics do not comply with this criterion.

The identification of the semantics of a social market economy's culture begins in the original ordoliberal sense - and I will take this up - with a fundamental confession for the market. It is a competitive economy with ethically desirable efficient allocations that avoids a waste of resources (Goldschmidt, 2006). Leadership ethics within the meaning of social market economy has to pursue the market-oriented target of economic efficiency. This aim is necessary but not sufficient. At the level of the economic system a frame is demanded that permits redistributions needing justification and other market regulations. The founding fathers of social market economy end up with their very own textual interpretation of these principles concerning the market and its autonomy. It is fundamental to have a human aim that is universally justified. Eucken justifies this strong demand in a Kantian sense, Müller-Armack in a religious sense (Müller \& Nass, 2013). Eucken, for instance, demands 
according to Kant's categorical imperative in its third version an economic system in which humans are not only a means to an end, not only particles of an apparatus. Social market economy serves the development of humans as a whole person. The humane aim of personality that is justified transcendently by Eucken is compulsory on the level of a leadership culture if it wants to converge with the basic idea of the economic system. It emphasises categorically human as an end in itself and its development as a person. This is the reason for the market's framing and it raises the question which role it should have, compared to the efficiency target. Leadership ethics must illustrate this normative bipolarity. Ethical orientated personnel management has the performance target to provide companies with good employees (Plaschke, Sauter \& Zinder, 2007). One can argue in terms of the founding fathers of social market economy about weighting of aims on the meso level. But this bipolarity of targets is constitutive as an implicit value basis for the leadership ethics in social market economy according to a further definition of leadership. Its elaboration has to interpret the leadership-relevant dualism of responsibility of efficiency and humane target systematically.

While the aim of efficiency is textual given by the economic market principle, the semantics of the humane aim is controversial. Paradigms competing each other can be found in business ethics: Either a monological heuristic of the Homo Oeconomicus (HO) can be taken as orientation of the humane aim according to K. Homann for instance; or a complex dialogical rationality of humans is assumed on an anthropological basis, represented by A. Smith, P. Ulrich, A. Sen etc. Furthermore egoistic and complex ethical motives of human beings in the human orientation for each case should be considered. ${ }^{1}$ The value basis requires a decision from a leadership ethic of social market economy on the fundamental understanding of the respective humane orientation. One should distinguish between the paradigms of a monological heuristic and a dialogical anthropology.

\subsection{Three Culture Principles of Leadership}

Principles of culture serve as help to answer the question about the relation between the efficiency and humane aim. They need to be understood categorically according to the value basis. This means that there is no need to re-construct them in a creative process of creation all the time or to negotiate it consensually. They are rather understood as a premise that does not create its ethics out of itself. However, enhancements of the catalogue are not excluded. Transcendental and religious grounds for the principles are in accordance with the basic idea. Alternative grounds capable to adapt are found in a new-Aristotelian idea of ability (e.g. A. Sen) or in a new metaphysical approach represented by Schramm (2015). Subsequently, there are non-arbitrary standards of a realistic ethic in an assumed social structure of the universe as the moral truth following Hartshorne (1964) and Whitehead (1978); these standards presume transcendentally a 'cosmological intrinsic value' so to speak. Different

\footnotetext{
1 A normative monological heuristics beyond egoistic rationality would be conceivable for instance according to the left libertarianism of P. Van Parijs, although it was not submitted business ethically and furthermore it is contradictory with market economy logic.
} 
accesses permit the grounds of principles that are considered to be objective. Solidarity, subsidiarity and market conformity are unquestionable to solve the dualism of human and efficiency goal. Eucken replenishes it with the following generalizable regulative principles: priority of the monetary policy, consistency of economic policy, open markets, freedom of contract, liability, private property, control over monopolies, progressive taxation, avoidance of external effects and the intervention against anomalies on the labour market (Goldschmidt, 2006). Moreover, the cultural program of social peace and solidarity is a crucial principle of culture.

The principles will be transformed now into a catalogue with leadership ethical relevance in terms of semantic clarity and complexity reduction. Since solidarity and subsidiarity have also fallen victim to the nominalism we have to search for meaningful alternatives. These alternatives are valid then in a model as veritable touchstones of a leadership ethic in social market economy:

1. The cultural program of social peace is a cultural peace-making Formula that assumes a symbiosis of economic, social and cultural policy. It is geared towards the protection of social peace and is not restricted to anonymously following the rules. In his interpretation to Rüstow describes Hegner (2000, p. 38) the threat of social peace in the following way: "The loss of superordinate values that are necessary for strong company in a community of solidarity and that give the individual an orientation for his action promote the coarsening of the individual together with a reciprocal alienation." 2 The formation of reciprocal confidence of the strong towards the weak and vice versa helps the political implementation of social market economy (Hegner, 2000, p. 90). Following the principle of leaders' and employees' reciprocal confidence leadership ethics can be asked: How is a culture of trust justified, understood and implemented?

2. Subsidiarity and market conformity justify the performance principle; position, remuneration and responsibility should comply with this. The principle of performance and liability together with an avoidance of external effects represent autonomy. Solidarity, progressive taxation and also the constitutional social responsibility of possession represent social responsibility. With a bipolar principle of liability leadership ethics can be asked: How are autonomy and social responsibility justified, understood and implemented?

3. $\quad$ The double principle of responsibility can be enriched as regards content with the principle of freedom. Freedom of contract and protection for private property do not only stand for a refusal of collectivisms but also for an avoidance of dictates (Battyány, 2007). They substantiate a demand of negative freedom as right of defence. But this is not enough. A demand of positive freedom is added with social responsibility. This is concretized in the new-Aristotelian capability approach of A. Sen. It postulates pre-positively justified human fundamental rights to essential

2 Translation by Elmar Nass. 
capabilities, such as health, creativity, autonomy and social integration (Sen, 1993, p. 31). These are reflections of freedom and should be granted to everyone. Self determination is designed as a room for decision-making that is objectively due to every human. According to this, freedom is an individual range of options of responsible deciding that allows appropriate choices between alternatives. Justice calls for a human's liberation of such positive ability of freedom by removing barriers of freedom of choice. The actual received features with main functions should not be equalized but the ability to develop main functions like these. The government is committed on the macro level by social rights to provide options for the development of human basic functions, for example with the aid of educational institutions and health facilities (Sen, 2003, p. 36). But these options improve the range of responsibility only if every individual is able to decide independently (Nussbaum, 1988 , p. 115). It is the responsibility of the individual how he uses educational offer or whether patients use hospitals being open for them. Sufficiency is understood as securing of a life saving minimum need but also an establishment of such a responsibility range of positive freedom; this should enable every individual to develop their talents but does attribute an unconditional right to compensation to those who omit these chances caused by them. This is in conformity with the idea of liability. According to Social Market Economy the idea of responsibility is interpreted in this way. For this reason leadership ethic must be asked: Does the represented understanding of responsibility correspond with this culture of freedom to enable?

The assertion of the freedom to enable representing the normative basic idea of Social Market Economy postulated here is not evident. Since this principle originates from the logic of dialogical anthropology that is also represented by Sen. The claim for an unfolding of human main functions interprets the semantically controverted human aim of basic values and with that the basic idea of Social Market Economy according to the freedom to enable. That is why this principle cannot be a criterion for an assessment of leadership ethics in the paradigm of a monological heuristics but only in the context from what it is extracted. In the case an introduction of this principle it is only because it seems to be congruent applied with reservations at its justification and semantics to the principle of the founding fathers. An understanding of Social Market Economy that interprets the human aim as a monological heuristics will put another principle into its place that correspondents with its paradigm. So, if the guideline will be developed below and will be brought to bear later it must be noticed that it can only represent the anthropological paradigm.

\subsection{Three Perspectives of Ethical Assessment}

For an assessment based on the main principles of culture, leadership ethics must be exposed to the relevant ethical perspectives. One must ask for equitable relations in a company always in reference to actors and rules. Hence primarily two perspectives appear immediately. Leadership culture is realised in the ethos of all involved: leaders and employees. Therefore, leadership ethics is first of all individual ethics but does not amount to nothing more than 
that. ${ }^{3}$ It is also an ethics of institution and asks personnel, organization and general policy departments perhaps for the composition of written and unwritten company rules such as models, organigrams, standards of hierarchy, decision-making routes and controlling as for the allocation of competences and delegation. Likewise it asks for the strategies of the intended culture of communication and motivation together with human resource planning, personnel placement and progress. That implies concrete answers to the following questions for example: Which personalities should prevail as leaders? ${ }^{4}$ Which employees should be hired? Which education schemes should be benefited? Should executives rely in their area of accountability more on cooperative or top-down decisions, more on control or on faith, more on competition or team? What should be favoured: mainly extrinsic financial aspects or intrinsic motivation out of discretion and identification?

The third perspective emphasizes the reciprocal relation of the first two perspectives as an own point of view. According to this leadership ethics is ethics of relationship that realises itself as a demanded culture in the togetherness of leaders and employees. This includes their behaviour towards the rules and their expectations and retroactive effects on the institutional level. This third perspective considers that institutions become concrete in their transactions; they continually influence evolving the culture of leadership as a whole (on individual ethos of participants and institutions) according to a dynamic idea of style. This again modifies the relation (Schramm, 2015. pp. 184-185). These continual reciprocal circumstances form own entities of culture. The content and the rank of loyalty or the identification of leaders and employees with the company with its rules and expectations characterize it.

\subsection{GILESMA - A Model}

The normative guideline can be transferred to a simple model. It is inspired by the comparable, but also in significant aspects deviating "model to ethical evaluation social-technical arrangements (MEESTAR)" from the field of health technology. The motivation to develop this model shows analogies to crisis of orientation in leadership ethics. This makes the basic idea of an ethical complexity reduction with the help of a model like MEESTAR promises attractive so that this transfer of theory is highly promising. In the end MEESTAR is simply a vivid cube of criterions of ethical evaluation that is developed by Manzeschke, Weber, Rother and Fangerau (2013). It was made known successfully considering the lack of a systematic-ethical orientation in the highly complex AAL- context of assessment. The promised ethical evaluation is designed three-dimensionally. Seven ethical principles are postulated as criterions (autonomy, security, privacy etc.) that are

\footnotetext{
${ }^{3}$ Rohrhirsch (2013) makes an objection against this from a Christian standpoint; there would be no Christian leadership ethics but only Christian leaders. It does not follow such a concentration on ethics of virtue. Its regression is favoured in the heuristic paradigm. Homann (1993, p. 41) warns of a non-economic endogenized moral of leaders and employees. To systemize and follow up on this standpoint is again the task of representatives of this paradigm.

${ }^{4}$ Kuhn and Weibler (2012) criticise for instance that Machiavellists, narcissists or psychopaths currently win the raise.
} 


\section{Macrothink Institute ${ }^{\mathrm{TM}}$}

evaluated with falsification according to three perspectives of observation in four steps of ethical sensitivity of technical assistance systems (from "harmless" to "refuse"). Following this, an overall assessment from the respective individual valuation takes place. The identification of principles like the assessment itself is subjected to a creative-discursive logic so that the seven criterions are replaceable hypothesis themselves. ${ }^{5}$

The classification in principles, perspectives and assessments can be used for the leadership ethical model of identification. The discursive norm does not apply here in accordance with the methodological universal claim of the value basis. Basic question and principles are not classified as hypothetical but as categorical. The individual assessments do not raise a categorical claim. They are scientific interpretations that may turn out to be different. The three-dimensional model is not a norm itself after all but as an evaluation tool a complexity reducing orientation for the identification of a leadership ethic of Social Market economy. The "guideline" to identify leadership ethic of Social Market economy will shorten to "GILESMA" hereafter.

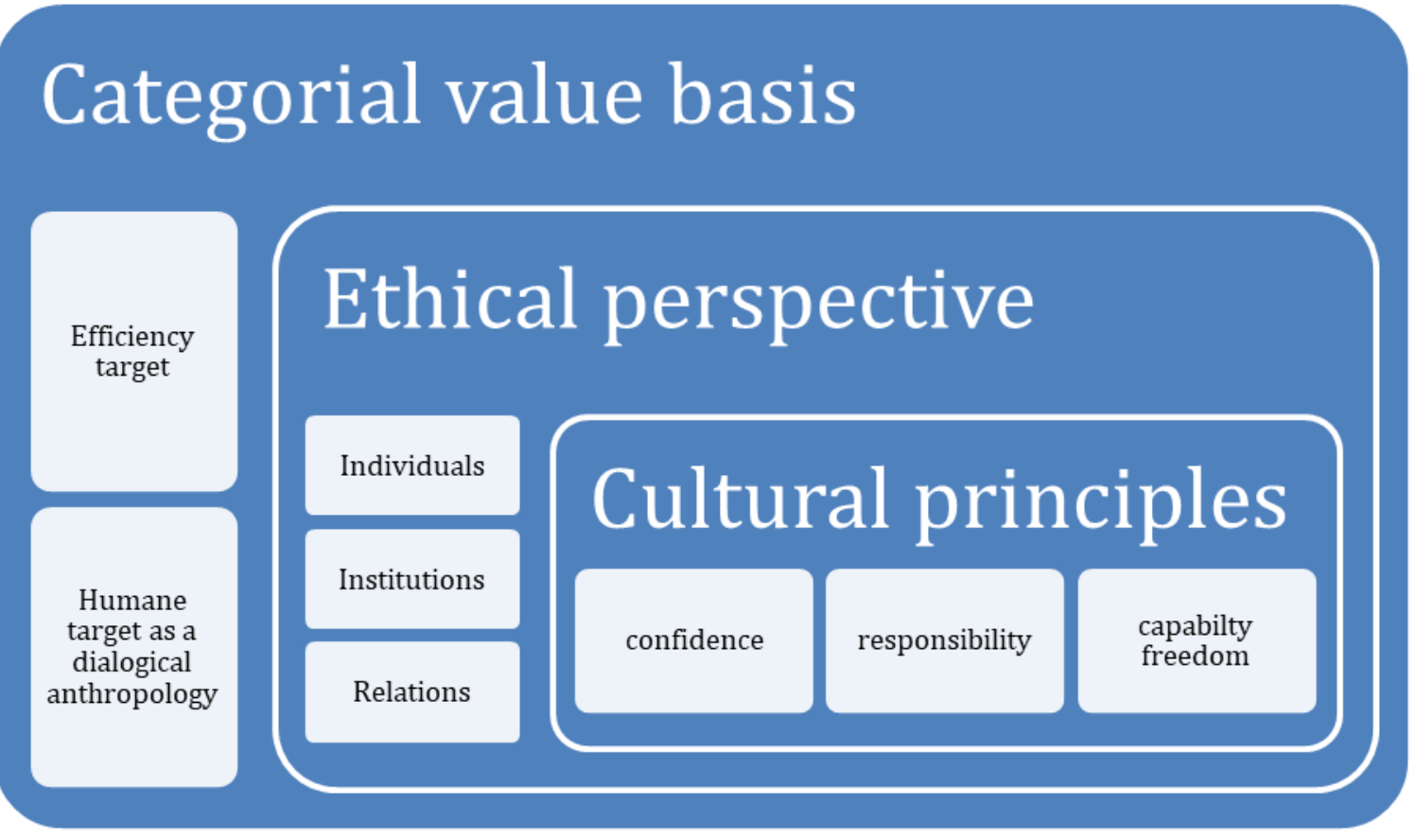

Figure 1. GILESMA - a model (own illustration)

If a theory is undergone by the GILESMA-assessment the first step is to decide whether it is an ethic: It has to have the basic questions of the source of values for theme. In a second step an allocation to one of the two human aims must be made. Then one must examine in a third step the three principles from the view of the three perspectives so that nine assessments must be performed here. An Overview over weakly and strongly marked cultural principles in the

\footnotetext{
${ }^{5}$ Cf. Manzeschke, Weber, Rother and Fangerau (2013): “the ethical relevant questions ... should be discussed in public to make good decisions in this sensitive and relevant field of Res publica before the normativity claims the de facto." (p. 106) Translation by Elmar Nass.
} 
context of the chosen paradigm can be arranged with that; whereby it is followed up on the anthropological paradigm with the principle of freedom to empower in the abovementioned sense. Result of this assessment is then in a fourth step the classification of a model for instance as a strong or weak theory of Social Market Economy. An emphasis of the nine valuation fields among others has not yet been performed in the guidelines. It remains a matter of scientific interpretation.

1 .

Application by means of the set of basic values

Four steps can be presented now. With these steps GILESMA can be applied in the assessment of leadership theory.

\subsection{First Step: Leadership Ethics or Theory?}

The first step of the application is to identify a leadership ethics of Social Market Economy with the help of a set of basic values. It is necessary to demand a togetherness of efficiency and human aim where one cannot offset the other. This dualism of responsibility focuses the view on employees in leadership ethics (Fischer \& Fischer, 2007, p. 22). If the leader sees employees firstly as a replaceable production factor leadership is about the summed optimisation of human capital in a company depending on products to be optimized by incentives by the motivation and qualification of the work force. Further personal preferences of those involved can be neglected. If the human is understood primarily as an end in itself then it is not firstly about the optimization of a summed output quantity in the design or implementation of a leadership ethos, rules and strategies where one or two may fall into bad ways. The aim is rather the personal development of every single person subject to concrete basic skills and variable personality traits (preferences). The efficiency target does not disappear from view with this. The suppression of an economic point of view is in a market-based context probably self-destructive for companies. The bottom line is that it needs motivated and well-qualified employees who realize their selves at the expense of the companies. There is otherwise an invitation to a moral hazard that weakens additional potential for identification. However, the attractive accumulation of performance potential is in deficit for an ethic that is not realized in an endogenized economic. Ethical leadership of Social Market economy has to keep the development of humans always in mind with all necessary calculation.

Ethical leadership incorporates human orientation as an end in itself. The present management models that block this aspect out in favour of a mere end in itself of efficiency may be seen as a theory of leadership but not as ethics. The non-ethical models can be differentiated between 1.) Those who limit humans monologically to the features of a Homo Oeconomicus and those 2.) Who understand humans dialogically with an egoistic and a sympathetic-ethical rationality. The first group includes economic imperialistic approaches. They understand entrepreneurial responsibility as a structural optimisation process of organisations following the logic of G. Becker and McKinsey. Malik (2007) subsumes desirable leadership qualities for instance for the purpose of optimized human capital: The hard aim of performance optimization is subordinated to secondary weak cultural destinations: such as the open goal of a climate of trust, strengthening of loyalty and identification, in the 
qualification of employees focus the attention on a weakening of weaknesses and a promotion of positive thinking. Personality development orientated at egoism is an instrument of economic success: Significant is not how humans are but how they act: the being (Sein) is not crucial but the doing (Malik, 2007, p. 79).

Attempts of the second group of non-ethical models admittedly understand humans as a dialogical being in terms of the anthropology of Smith. They even care about the unfolding of humans in this quality. However, the aim is a secondary and interchangeable one subjected to the efficiency target dominating alone and is exploited (Sims \& Brinkman, 2003, p. 243). The personal development and with that is a man a means to an end of efficacy. Frey et al. (2010, p. 643) represent this view of a so-called 'bright side of leadership', after which moral is a success factor: The consideration of employees' aspirations brings added value to esteem. For Kets de Vries (2009) understanding employees is a success strategy, confidence is the path to higher performance. Basic assumptions of a theory like this are not evident at all, because there is also a dark side of leadership that is only orientated on efficiency. ${ }^{6}$ Even if the assumptions of the bright side would be correct it is no ethical leadership of Social Market Economy. Although the results of practical leadership might felt in a positive way, a relativized diversion of the human target is the exclusion criterion. A further valuation by GILESMA becomes superfluous. The same applies for theories that sacrifice the efficiency target. These might be ethics, but not ethics of Social Market Economy.

Two alternative groups of ethical leadership of Social Market Economy remain now. Both of them include the human goal as an end in itself as a value basis. This is necessary because the unfolding of man as a person is - reasoned transcendentally with Eucken - an immediate consequence of the categorical imperative that treats humans not alone as a means to an end but also as an end in itself. The exploitation of individuals for an economic calculation is ethically interdicted. In doing so a monological heuristics of homo oeconomicus will be taken as a basis agreeing with the already presented schools. The economic calculation would then serve the development of human moulded like this. The efficiency orientation is an exploited mean to an end of a previously heuristic simplified idea of humans. A complex anthropologically justified dialogical rationality can be postulated alternatively here. A unfolding of this rationality is then in sense of a human aim an end in itself.

\begin{tabular}{l|l|l}
\hline & $\begin{array}{l}\text { Human aim as an end in } \\
\text { itself (Ethics) }\end{array}$ & $\begin{array}{l}\text { Relativized human aim (no } \\
\text { ethics) }\end{array}$ \\
\hline Dialogical anthropology & $\begin{array}{l}\text { Dialogical development as an } \\
\text { end in itself }\end{array}$ & $\begin{array}{l}\text { Exploited } \\
\text { unfolding }\end{array}$ \\
\hline Monological heuristics & $\begin{array}{l}\text { Efficiency target with a } \\
\text { HO-unfolding as an end in } \\
\text { itself }\end{array}$ & Economic imperialism \\
\hline
\end{tabular}

\footnotetext{
${ }^{6}$ Attempts like this orientated themselves on Machiavelli. Cf. Kellermann (2004, p. 5). Reference to success only is the criterion to distinguish between a strong and a weak leadership.
} 
Figure 2. Identification of leadership ethics (own illustration)

\subsection{Second Step: Heuristic or Anthropological Set of Basic Values?}

It has been shown why a monological heuristics and a dialogical anthropology are acknowledged as two competitive paradigms of leadership ethic of Social Market Economy and they have to be distinguished. The second step now has to identify these necessary allocations in the leadership ethics for consideration also to decide about a further application of GILESMA.

Monological models of economics see the man operating on the market heuristically as an instrumentally rational Homo Oeconomicus. Accordingly, people should follow this logic both in the design of the rules in a business company and in the concrete moves of a company. A morality differing is redundant and even harmful (Homann \& Blome-Drees, 1992). The human aim is here endogenized in the efficiency targets with the result that the synthesis for the dualism of responsibility is identical with an economically justified responsibility. The price accepting consciously for this is the contraction of man on heuristic grounds that are estimated to be unrealistic by economists. ${ }^{7}$ Especially economic theories of executives of Homann's circle of students are associated with this heuristic paradigm.

A dialogical anthropology can invoke A. Smith (2005): "How selfish soever man may be supposed, there are evidently some principles in his nature, which interest him in the fortune of others, and render their happiness necessary to him, though he derives nothing from it except the pleasure of seeing it." (p. 4) The human target of ethics cannot be limited monologically on the development and support of egoistic maximising of the utility for one self under those conditions, because this reduction of man is shorten in the fade-out of altruistic or even deontological rationality (Sen, 1993, p. 31) and the implementation of such ethics does not do justice to it. If this anthropology is preferred to the heuristics then it is the task of a leadership indebted to the human aim to take both natures equally seriously and understand man as a dialogical being in this sense. For example, leadership ethics that follow the anthropological assumptions of the dialogical rationality by Ulrich (2008) have to be dedicated to this paradigm. Ulrich's problem is the explicit application of discourse-ethical logic that does not coincide with the source of values of Social Market Economy. However, Kant's universalistic ethic is used for the rationale of his dialogical anthropology; which in turn is compatible with Eucken's regulatory ideas for instance.

With a meticulous classification of the examined approach of leadership ethics in one of the both paradigms the second step has been taken with the aid of the GILESMA- source of

7 The Governance-theorist Tricker (2012, p. 62) follows this fundamental critique regarding the economic approach of the agency-approach that is very close: "agent theory argues that is has been erected on a single, questionable abstraction that governance involves a contract between two parties, and is based on a dubious conjectural morality that people maximize their personal utility." The economists Stutzer et al. (2010) state: A paradigm change becomes apparent, not only methodically, but also contextually. Also results of the experimental economic research are a challenge for the mainstream-economy. They show altruistic and conducted by justice behaviour that seem to be contradictory with the paradigm of HO. 
values before an individual valuation follows. These can now be shown for the anthropological paradigm.

\section{Application with the Aid of Principles and Perspectives}

\subsection{Third Step: Individual Valuation}

In this third step attempts are made to identify in each case the intensity of three cultural principles in the ethics that need proof out of the three ethical perspectives. An exemplary concept of leadership ethically relevant contents for the valuation follows as an orientation for a concrete use of GILESMA, structured in three cultural principles.

\subsubsection{Culture of Trust}

Theory of leadership distinguishes between Theory $\mathrm{X}$ and Theory $\mathrm{Y}$ with the equivalent consequences for the form of the culture of trust with regard to the comprehension of human of leaders since McGregor (1960).

Theory $\mathrm{X}$ objects the anthropological dialogical paradigm because humans are not understood as moral beings in the context of companies. This theory is presented as a background of a counter model: The employee is considered to be opportunistic and egoistic. As he uses every possibility to moral hazard that harms the company it is institution ethical necessary to have an intensive control system with appropriate sanctioning instruments (McGregor, 1960, pp. 33-35). Leadership is then understood transactional according to the categorisation of Burns (1978) and the continuation of Bass (1985). This means: As human are not morally convertible in companies and therefore an appropriate re-education is said to be utopian individuals must behave relation-ethical to the rules in this way that opportunistic employees adapt at least to expectations; while it does not depend on shared ideals or visions (Burns, 1978, p. 20). Transactional leadership is based on control, extrinsic reward and sanctioning: Those who are guided have to expect positive or negative consequences that are conveyed by the leader for that what they can do or avoid. (Neuberger, 2002, p. 197). Controlling is supposed to reduce opportunistic behaviour. An executive has to design successfully the tension between power and countervailing power to the employees and must assert oneself in this conflict. Adaptability such as respect for prescribed rules and sanctioning is one job requirement for executives and employees. Non-executive employees should not only trust in rules but also in the leader. There is less demand for creativity and discussions because this would block the implementation of decision-making processes and it would undermine the required Principal-agent-principle.

"The Kantian adopts the Theory Y view of human nature" (Bowie, 1999, p. 86). Kantian and generally anthropological-dialogical leadership ethics rely on a culture of trust and esteem as an end in itself. According to this and the Stewardship approach (e.g. Tricker, 2012) is initially assumed that employees are loyal, ready for work and motivated. They want to spread responsibility and creativity. One must rely in the business culture of reciprocal confidence on self-control (McGregor 1960, p. 47-48). The rules serve institution ethical this culture. They do not replace the individual morality of agents. A theory like this can be relation ethical implemented in a transformational (resp. transformative) leadership. It is 
based on intervention for the purpose of identification as with vision and mission, for instance by charisma, inspiration, intellectual stimulation or individualised leadership (Neuberger, 2002, p. 199). It is realised individual ethical either by a charismatic-heroic understanding of leadership according to which employees must be educated; or by a post-heroic understanding of leadership according to which a rather silent leader makes participative decisions (Kuhn, 2000, p. 160). Their aim is the preferably comprehensive takeover of joint responsibility with an anxiety-free critical-creative loyalty.

\subsubsection{Culture of Responsibility}

Leadership ethics has to provide a rationale of responsibility in accord with the value basis. For this purpose as a basis for individual ethical virtues of leadership a Kantian and a Christian variant will be introduced exemplary. ${ }^{8}$ Ethically legitimated leadership assumes from a Kantian sense autonomous executives who enable the employees for autonomy in the responsibility facing the moral law: “... one has both a duty of perfection to oneself and a duty to promote the happiness of others" (Bowie \& Werhane, 2005, p. 64). First of all humans are responsible for necessity of thinking of rationality, deduced from that in front of oneself, to unfold their autonomy. Analogical thinking applies to a Christian leadership ethics. Accordingly, humans are moral existences as free and social beings that come to decision in basically dialogical self-serving and socially orientated strategies with the aid of conscience. From a Christian point of view human bear threefold responsibility in the sense if the threefold biblical commandment of love, first of all towards the Creator who gave human the freedom of self determination and mission for the good thing. Deduced from this he has the task towards himself to unfold his individual and social personality and to value every human life especially this of the weak. Thirdly the responsibility towards fellow human beings is an order for love of neighbour that is realised relation ethical even in an affective spirit of togetherness. In a Kantian as well as in a Christian sense executives have threefold responsibility. The rules for the fulfilment of the human aim should enable institutional ethical the development of this responsibility (for instance by a specific training, flat hierarchy, delegation, cooperative decisions, attitudes of respective employees). Participative leadership is not understood as consensus democracy. In fact, it is accounted for by the autonomy of individuals in a Kantian sense with the result that there are different interests that cannot be headed to a consensus even with discourse. It is the task of executives to organise a balance between different interests and also to stand differences of opinion: "We should prefer a theory that leadership that allows a place of disagreement and dissent" (Bowie \& Werhane, 2005, p. 142). This includes a convincing enforcement power, too. (cf. ibid., p. 147). Relation ethical target is a symbiosis of efficiency and human aim by a modified habitual thinking and acting: "This leadership happens when one ore more people connect with each other so that leaders and followers raise each other to a higher level of motivation and morality." (Burns, 1978, p. 20). Post heroic leaders treat employees as independent co-respondents for instance. Promising task should be delegated as a rule, whereas - as far as

\footnotetext{
8 A justification according to business metaphysics (Schramm, 2015) or Aristotelian derivation would be appropriate, too.
} 
possible - responsibility for mistakes of those who are lead should be accepted (Kuhn, 2000, p. 160).

Transformational leadership is reflected in the fact that it wants to convert employees to autonomous actors who are jointly responsible. Even those who are lead head executives by their behaviour and are understood as 'co-leaders' in this sense. The empowerment for this requires transparency of decision paths and arguments as well as a mutual provision of all needful information for a rational jointly responsibly decision ('open book management') (Bowie, 1999, pp. 54-57). As the circumstances require, personal responsibility can be interpreted in the sense of autonomy in the way that intrinsic motivation should replace extrinsic motivation of employees. For example, R. Sprenger emphasised the formula of success of autonomous leadership in his narrative bestseller at the end on the nineties and gave warning of too much praise for employees in a company. This is a relation ethical disputatious advice.

\subsubsection{Culture of Empowerment}

An obligatory duty to guarantee negative freedom as "ability to act independently of determination by alien causes" (Bowie, 1998, p. 1085) is a necessary condition for a culture of capability freedom. ${ }^{9}$ Compulsion and deception should be avoided by all means. Even a paternalism that dictates employees an idea of good living is unwanted (Bowie, 1999, p. 71). A further target of meaningful work is the support of the unfolding of positive freedom "to be a law unto themselves" (ibid., p. 63). On that point, the range of options for free decision (including exit-options) should be extended by educational offer for instance. Rational decision-making ability and a moral development should then again be encouraged to enable employees to personally unfold their positive freedom (ibid., p. 70). This includes the support of integrity of leaders and leaders and employees by understanding their tasks. ${ }^{10}$ It is about autonomy that is more than a value-oriented charismatic giving orientation. Integrity is believed to be an unambiguously positive commitment of values that realises itself in personal coherence and fortitude even against resistances (Kuhn \& Weibler, 2012, pp. 111-113). In the sense of the principle 'ultra posse nemo tenetur' leaders have a range of options themselves in the concrete realisation of supporting positive freedom. They can decide which measures might be useful. Different leadership ethics try respective implementations.

Kantian (and also a systematic, still need to be developed Christian) leadership ethics are institutional ethical control and strategy concepts of a freedom to enable of capacity building. Self-purpose objectively understood is the empowerment of humans to accept the triple

${ }^{9}$ Cf. Korsgaard (1996, p. 113). A compulsory redundancy is therefore justifiable if employees let themselves in for this risk in a voluntary employment contract. Cf., too: Bowie (1999, pp. 48-53).

${ }^{10}$ Integrity is demonstrated by a professional qualification, by experiences in the interaction with people, by a consistent personality, by a orientation on justified values, by showing emotions and living positive virtues. 
responsibility. This becomes concrete in the rules that enable thereto as a guarantor of positive freedom. Besides that, the individual ethical unfolding of non-egoistic virtues in all areas of life is the expression of this freedom; performance, motivation, loyalty and cooperativeness follow. Both the design of rules and strategies in a company and concrete moves are methodical locations of moral.

Servant leadership understands empowerment in accordance with the wishes of post heroic ideals. The entrepreneur R. Greenleaf (1904-1990) created the vision of a serving attitude of leaders inspired by H. Hesses 'Morgenlandfahrt'. The serving self-conception of a leader demanded individual ethically should inspire employees relation ethically to have personal and shared responsibility and empower them (Hartmann, 2013). Evangelical advancements such as the ones by K. Blanchard, P. Hodges or K. Jennings present an understanding of leading with the motto 'Lead like Jesus'. Basics and virtues are stringed together here with intuitive references to the bible such as 'Heart, head, hands and habit'; the right motivation, the presence of a vision like stout behaviour with spiritual is meant by this; or for example the virtue of the precursor, of the visionary achievement motivator or others. J. Sipe's and D. Frick's secular vision offers a matrix with 21 leadership skills that are divided in 7 categories (communicator, team worker, moral authority, systematic thinker, moral fibre, vision to take humans primarily in account).

Likewise the anthroposophical leadership ethics advocates a strong idea of empowerment; it is implemented consequently by G. Werner for instance with the drugstore chain $\mathrm{dm}$ on the basis of an ideological transparent made humane aim (Dietz, 2007). Beginning with the individual ethically idea that has to be reduced of a material abandoned self-redemption it is about making leaders relation ethically to evocation of the creativity that is inherent in every human. Employees must be empowered to find their inner balance by discovering and developing their inhering entrepreneurial talent. This culture of reciprocal empowerment would lead to intrapreneurship as a symbiosis of efficiency and human aim, to a high identification with oneself and with the company affiliated to an affective communal spirit. Economic success should be understood as a derived target; the so-called refinement of every human should not be sacrificed for this cause. On this basis, Werner (2006, p. 29) can describe the transformational target of a culture to empower for a leadership ethics orientated on the anthroposophical conception of man in the following way: "A distinction between the performance of a dictate and action out of own discretion cannot be seen from the exterior. But this difference is crucial."

\subsection{Forth Step: Overall Evaluation}

After the implication of GILESMA nine individual valuations for the accordance with the basic idea of social market economy exist in the best case. In the course of this there will probably be gaps in the concrete examination of models of leadership ethics if there is a lack of identifiable answers to the individual topics. Attention should be paid to the question whether a principle in total or a perspective is blanked out. In this case an overall evaluation should note this critically. Individual valuations must be questioned again in regard to their interaction with other cultural principles. For example, a relation ethically positively assessed 
culture of empowerment of a servant-leadership model might be confronted with a potential hazard determined by this of the autonomy of leaders because of a overcharging self-abandonment especially towards the organisation (in the field: individual ethical autonomy). As Bowie and Werhane (2005, p. 143) comment on this topic: "The danger of the servant leader is that he or she should allow him- or herself to be used as a means merely". Analogical thinking applies to an anthroposophic model of transactional leadership with possibly paternalistic consequences. Subsequently evaluation of assessment must be undertaken. As a result, there is an evaluation as strong or weak theory of social market economy and a corresponding recommendation regarding its application in the company in the light of cultivating Social Market Economy.

\section{Prospect}

GILESMA identifies the basic question of leadership ethics of Social Market Economy in the dualism of responsibility of efficiency and human target. The model helps to distinguish basically between leadership ethics and other theories of leadership on this basis. It is an instrument but it interprets Social Market Economy afterwards in the light of capability freedom in due consideration of virtue ethical perspectives. With this, the anthropological paradigm has a guideline for the evaluation of concepts of leadership ethics; whereby, it can and must be discussed about the reduction of complexity undertaken here (for example a possible need for supplementation of the culture principles), as well as the strong Kantian impact (Bowie) that might or might not be shared. I think a Christian enrichment is possible and rewarding as soon as a comprehensive systematics of Christian leadership ethics exists.

It bears an analogous guideline for the alternative heuristic paradigm. It basically can orientate itself towards the presented model; as it is here also about the identification of leadership ethics of Social Market Economy. A revision of the freedom of empowerment is expected in the cultural principles, in the perspective this of the individual ethics. Following this, a analogous testing of leadership ethics can be realised with this in the context of every paradigm. Even modals whose association is not obvious can be evaluated by two guidelines, which promise a productive dialogue of respective results. ${ }^{11}$

\section{References}

Bass, B. (1985). Leadership and Performance beyond Expectations, New York: Free Press.

Battyány, P. (2007). Zwang als Grundübel in der Gesellschaft? Der Begriff des Zwangs bei Friedrich August von Hayek, Tübingen: Mohr Siebeck.

Bowie, N. (1998). A Kantian Theory of Meaningful Work, in: Journal of Business Ethics, 17, 1083-1092. https://doi.org/10.1023/A:1006023500585

Bowie, N. (1999). Business Ethics. A Kantian Perspective, Oxford: Wiley-Blackwell.

Bowie, N., \& Werhane, P. (2005). Management Ethics, Oxford: Wiley-Blackwell.

${ }_{11}$ My Thanks for translation assistance goes to Sophie Zintl and Start Fellows. 
Burns, J. M. (1978). Leadership, New York: Harper.

Dietz, K. M. (2007). Die ontologische Grundlage der Autonomie des Menschen und ihr Rang in der modernen Führungspraxis, in: Schreckenberger, W. (eds.): Recht, Staat und kulturelle Entwicklung, Speyerer Arbeitsheft Nr. 191, Speyer: 97-109.

Dietzfelbinger, D. (1998). Soziale Marktwirtschaft als Wirtschaftsstil. Alfred Müller-Armacks Lebenswerk, Gütersloh: Gütersloher Verlagshaus.

Eucken, W. (1952/2004). Grundsätze der Wirtschaftspolitik, $7^{\text {th }}$ edition, Tübingen.

Fischer, L., \& Fischer, O. (2007). Sind zufriedene Mitarbeiter gesünder und arbeiten härter? In: Personalführung, 40(3), 20-32.

Frey, B. F. et al. (2010). Unternehmenserfolg durch ethikorientierte Unternehmens- und Mitarbeiterführung. In: Meier, U., \& Sill, B. (eds.): Führung, Macht, Sinn, Regensburg: Pustet: 637-656.

Goldschmidt, N. (2006), Walter Eucken: Grundsätze der Wirtschaftspolitik (1952), in: Herz, D., \& Weinberger, V. (eds.), Lexikon der ökonomischen Werke, Düsseldorf: 129-130.

Hartmann, M. (2013). Servant Leadership in diakonischen Unternehmen, Stuttgart: Kohlhammer.

Hartshorne, C. (1948/1964). The Devine Relativity. A Social Conception of God, New Haven - London.

Hegner, J. (2000). Alexander Rüstow. Ordnungspolitische Konzeption und Einfluß auf das wirtschaftspolitische Leitbild der Nachkriegszeit in der Bundesrepublik Deutschland, Stuttgart: Lucius \& Lucius. https://doi.org/10.1515/9783110504521

Homann, K. (1993). Die Funktion der Moral in der modernen Wirtschaft, in: Josef Wieland (ed.): Wirtschaftsethik und die Theorie der Gesellschaft, Frankfurt a.M.: Suhrkamp: 32-53.

Homann, K., \& Blome-Drees, F. (1992). Wirtschafts- und Unternehmensethik, Göttingen: Vandenhoek \& Ruprecht.

Kellermann, B. (2004). Bad Leadership. What it is, how it Happens, why it Matters, Boston: Harvard Business Review Press.

Kets de Vries, M. (2009). Führer, Narren und Hochstapler. Die Psychologie der Führung, Stuttgart: Schäffer-Poeschel.

Korsgaard, C. (1996). Creating the Kingdom of Ends, New York: Cambridge University Press. https://doi.org/10.1017/CBO9781139174503

Kuhn, T. (2000). Internes Unternehmertum. Begründung und Bedingungen einer ,kollektiven Kehrtwendung', München: Springer.

Kuhn, T., \& Weibler, J. (2012). Führungsethik in Organisationen, Stuttgart: Kohlhammer.

Malik, F. (2007). Management. Das A und O des Handwerks, Frankfurt a.M.: Campus. 
Manzeschke, A., Weber, K., Rother, E., \& Fangerau, H. (2013). Ergebnisse der Studie. „Ethische Fragen im Bereich altersgerechter Assistenzsysteme“, München.

McGregor, D. (1960). The Human side of Enterprise, New York: McGraw-Hill Professional (1000).

Melé, D., \& Cantón, C. G. (2014). Human Foundations of Management. Understanding the Homo Humanus. Palgrave Macmillan. New York: Palgrave Macmillan.

Müller, C., \& Nass, E. (2013). Normative Grundlagen des Ordoliberalismus, in: Pribyl, H. (ed.): Die Weltwirtschaftskrise. Lösungsansätze aus christlich-ethischer Sicht, Heiligenkreuz: Sarto: $157-183$.

Neuberger, O. (2002). Führen und führen lassen, $6^{\text {th }}$ edition, Stuttgart: Lucius $\&$ Lucius.

Nussbaum, M. (1988). Die Natur des Menschen, seine Fähigkeiten und Tätigkeiten: Aristoteles über die distributive Aufgabe des Staates, in: dies. (1999). Gerechtigkeit oder Das gute Leben, Frankfurt a.M.: Suhrkamp: 86-130.

Plaschke, J., Sauter, W., \& Zinder, T. G. (2007). Personalmanagement, Berlin: Lehrbuch-Verlag.

Rohrhirsch, F. (2013). Christliche Führung - Anspruch und Wirklichkeit. Führen mit Persönlichkeit und Ethik, Berlin: Springer. https://doi.org/10.1007/978-3-658-02154-2

Schramm, M. (2015). Die Ethik der Transaktion. Warum eine Business Metaphysics im operativen Management nützlich ist, in: Maring, M. (ed..). Vom Praktisch-Werden der Ethik in interdisziplinärer Sicht: Ansätze und Beispiele der Institutionalisierung, Konkretisierung und Implementierung der Ethik. Schriftenreihe des Zentrums für Technik- und Wirtschaftsethik am Karlsruher Institut für Technologie. Vol. 7. Karlsruhe: 173-191.

Sen, A. (1993). Capability and Well-Being, in: Nussbaum, M., \& Sen, A. (eds.) (2002). The Quality of Life, $8^{\text {th }}$ ed., Oxford: 30-53.

Sen, A. (2003). Commodities and Capabilities, $7^{\text {th }}$ ed., New Delhi.

Sims, R. R., \& Brinkmann, J. (2003). Enron Ethics (or: Why Culture Matters more than Codes). In: Journal of Business Ethics, 45(3), 243-256. https://doi.org/10.1023/A:1024194519384

Smith, A. (ed. 2005). The Theory of Moral Semtiments. Edited by Sálvio M. Soares. MetaLibri.

Stutzer, A. et al. (2010). Normative und positive Grundlagen der Glücksforschung. Antrag zu einem bei der DFG eingereichten Forschungsprojekt, Münster/Basel.

Tricker, B. (2012). Corporate Governance. Principles, Policies and Practices, $2^{\text {nd }}$ ed., Oxford: University Press.

Ulrich, P. (2008). Integrative Wirtschaftsethik: Grundlagen einer lebensdienlichen Ökonomie, 4. Aufl., Bern/Stuttgart/Wien: Haupt. 
von Oelsnitz, D. (2012). Einführung in die systemische Personalführung, Heidelberg: Carl Auer.

Werner, G. (2006). Führung für Mündige. Subsidiarität und Marke als Herausforderungen einer modernen Führung, Karlsruhe.

Whitehead, A. N. (1929/1978). Process and Reality. An Essay in Cosmology. Gifford Lectures Delivered in the University of Edinburgh 1927-28, edited by D.R. Griffin/D. W. Sherbume, New York/London.

\section{Copyright Disclaimer}

Copyright for this article is retained by the author(s), with first publication rights granted to the journal.

This is an open-access article distributed under the terms and conditions of the Creative Commons Attribution license (http://creativecommons.org/licenses/by/4.0/). 